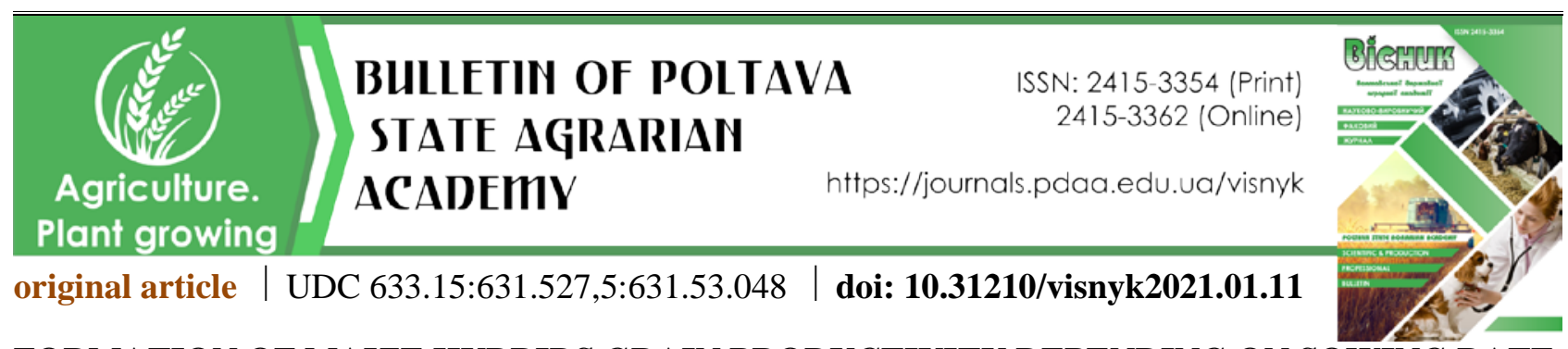

FORMATION OF MAIZE HYBRIDS GRAIN PRODUCTIVITY DEPENDING ON SOWING RATE
H. P. Zhemela
O. V. Barabolia*
V. V. Liashenko
Ye. S. Liashenko
V. A. Podoliak

ORCID (iD) $\frac{0000-0003-0167-7219}{0000-0003-4123-9547}$
ORCID (iD)
ORCID (iD) $\underline{\underline{0000-0003-0177-6209}}$

Poltava State Agrarian Academy, 1/3, Skovorody str., Poltava, 36003, Ukraine

*Corresponding author

E-mail: olga.barabolia@ukr.net \begin{tabular}{l|l} 
How to Cite & $\begin{array}{l}\text { (2021). Formation of maize hybrids grain productivity depending on sowing rate. } \\
\text { Bulletin of Poltava State Agrarian Academy, (1), 97-105. } \\
\text { doi:10.31210/visnyk2021.01.11 }\end{array}$
\end{tabular}

Zhemela, H. P., Barabolia, O. V., Liashenko, V. V., Liashenko, Ye. S., \& Podoliak, V. A.

Maize is universal due to its using as fodder, technical and food crop, which determines the topicality of increasing its productivity both in Ukraine and around the world. The aim of the article was to study the dependence of grain productivity of maize hybrids on sowing rates. In the process of research, field and quantitative methods, observation, and calculation method were used. Our research has shown that on the average over the study years, the minimum growing season was observed in P8521 early-maturing hybrid - 122.8 days, the longest - in PR38N86 mid-ripening - 131.1-133.7 days, in PR39B76 mid-early ripening - 125.4127.5 days. The duration of interphase periods and the growing season of maize hybrids depended on their biological characteristics and weather conditions and almost did not change under the influence of plant density. It has been determined that according to biological features of mid-ripening crop hybrid higher plants were formed than in early-ripening hybrids. With increasing the density of the above mentioned hybrids, a decrease in plant height by 2.7, 3.4 and $3.3 \mathrm{~cm}$, respectively, was observed. Thus, in the panicle flowering phase, when maize plants reached their maximum height, in the wet year it grew from sparse to overcrowded crops, and in the arid year it decreased. The studies have shown that individual productivity indicators decrease at overcrowding. In our opinion, the main reserve for increasing the production of commercial grain is determining the optimal density for maize hybrids of different ripening groups, taking into account agro-ecological conditions. The optimal number of maize ears, at which indicators of individual productivity and the number of plants per area unit are best combined, was achieved in P8521early-ripening hybrid in the variants with plant density of 75 thou/ha, in PR39B76 mid-early ripening - 70 thou/ha, and PR38N86 mid-ripening- 70 thou/ha.

Key words: maize hybrids, maturity groups, seeding rates, overcrowding, vegetation, yield.

\title{
ФОРМУВАННЯ ПРОДУКТИВНОСТІ ЗЕРНА ГІБРИДАМИ КУКУРУДЗИ ЗАЛЕЖНО ВІД НОРМИ ВИСІВУ
}

\author{
Г. П. Жемела, О. В. Бараболя, В. В. Ляшенко, С. С. Ляшенко, В. А. Подоляк \\ Полтавська державна аграрна академія, м. Полтава, Україна
}

Кукурудза є універсальною через ї̈ використання як кормової, технічної та продовольчої культуpи, що обумовлює актуальність підвищення їі продуктивності як в Україні, так і в усьому світі. Метою статті є дослідження залежності продуктивності зерна гібридів кукурудзи від норм висіву. 


\section{СІЛЬСЬКЕ ГОСПОДАРСТВО. РОСЛИННИЦТВО}

Під час досліджень використано польовий та кількісний методи, спостереження, розрахунковий. Результати наших досліджень свідчать, що в середньому за роки експерименту мінімальний період вегетаиії спостерігався у ранньостиглого гібрида Р8521 - 122,8 діб, найтриваліший-у середньостиглого PR38N86 - 131,1-133,7 доби, середньораннього PR39B76 - 125,4-127,5 дні. Тривалість міжфазних періодів та періоду вегетаиії гібридів кукурудзи залежсала від їхніх біологічних особливостей та погодних умов і майже не змінювалась під впливом густоти стояння рослин. Визначено, що відповідно до біологічних особливостей у рослин середньостиглого гібрида формувались рослини з більшою висотою, ніж у скоростиглих. При збільшенні густоти вищезазначених гібридів спостерігалося зменшення висоти рослин на 2,7 cм, 3,4 і 3,3 см відповідно. Отже, у фазу цввітіння волотей, коли рослини кукурудзи досягали своєї максимальної висоти, у вологий рік вона зростала від зріджених до загущених посівів, а в посушливі зменшувалась. Дослідження підтверджують, щяо показники індивідуальної продуктивності зменшуються по мірі загущення. На нашу думку, основним резервом збільшення виробництва товарного зерна є визначення оптимальної густоти для гібридів кукурудзи різних груп стиглості, зважаючи на агроекологічні умови. Оптимальної кількості качанів, при якій найкраще поєднуються показники індивідуальної продуктивності і кількості рослин на одинищі площі, у ранньостиглого гібрида Р8521 досягали у варіантах з густотою стояння 75 тис./га, у середньораннього PR39B76 - 70 тис./га і середньостиглого PR38N86 - 70 mис./za.

Ключові слова: гібриди кукурудзи, групи стиглості, норми висіву, загущення, вегетачія, врожсайHicmb.

\section{Вступ}

Нині кукурудза - одна з найпоширеніших культур у світовому рослинництві, займає третє місце після пшениці і рису. Універсальність іï полягає в тому, що використовується як кормова, технічна та харчова культура. Одержання стабільно високих урожаїв зерна кукурудзи є актуальним для сільського господарства України та інших країн $[14,15]$.

Кукурудза в Україні традиційно $є$ цінною продовольчою культурою. Вона все ширше використовується в харчовій промисловості, насичуючи ринок сучасною корисною і високоякісною продукцією [2]. Високо ціняться такі продукти харчування, як кукурудзяне масло, крупа, борошно, крохмаль, глюкоза, спирт, кукурудзяні пластівці, баранці, консервоване зерно тощо [11]. Все більше значення ця культура займає у фармацевтичній промисловості, зокрема, кукурудзяні маточки, пророщені зародки, каротиноїди.

Причини, що заважають прискореному зростанню валових зборів зерна, добре відомі - це недотримання агротехніки вирощування зернових, порушення технологічної дисципліни [9]. Далеко не скрізь забезпечується оптимальна густота рослин, допускається висока забур'яненість посівів унаслідок порушення в системі основного і передпосівного обробітку грунту та догляду за посівами [10, 13]. Крім того, урожай втрачається в результаті значної тривалості терміну збирання. Не використовуються широкі можливості сучасних гібридів [12].

Зарубіжні фірми пропонують насіння різних за стиглістю та продуктивністю гібридів, які потребують глибокого і детального вивчення в нових умовах вирощування та рекомендації найбільш продуктивних у виробництво [20]. Компанія «Ріоnеer» щорічно проводить у господарствах різних кліматичних зон України 287 ДЕМО з вирощування різних за стиглістю, офіційно зареєстрованих, гібридів кукурудзи. Для прогнозованого впливу на продуктивність цієї культури виробничник повинен чітко уявляти як той чи той агроприйом вплине на ріст і розвиток рослини. Серед факторів, що забезпечують високий урожай кукурудзи, значне місце займають просторове і кількісне розміщення рослин на площі, що має велику цінність і має на меті скоротити енерговитрати та підвищити рентабельність вирощуваної продукції $[5,6,7]$.

Основу виробництва кукурудзи в Україні становить вирощування гібридів, більшість із яких є простими міжлінійними, при цьому виникає проблема довготривалого вирощування гібридного насіння.

Оптимальна густота рослин є одним із найважливіших факторів для одержання високих урожаїв кукурудзи [22].

Одним 3 основних шляхів підвищення врожайності та зниження собівартості насіння є підвищення густоти вирощування рослин. Однак при цьому необхідно пам'ятати, що у разі надмірного загущення рослин погіршуються елементи структури врожаю та якість насіння $[13,14]$. Тому вивчення реакції кукурудзи до загущення та ширини міжрядь є дуже актуальною задачею рослинників. 


\section{СІЛЬСЬКЕ ГОСПОДАРСТВО. РОСЛИННИЦТВО}

Мета дослідження: визначити залежність продуктивності зерна гібридів кукурудзи від норм висіву.

Завдання дослідження: визначити тривалість міжфазних періодів вегетації гібридів кукурудзи різних груп стиглості залежно від густоти стояння рослин; дослідити динаміку росту рослин гібридів кукурудзи різних груп стиглості залежно від густоти стояння рослин; вивчити індивідуальну продуктивність рослин гібридів кукурудзи різних груп стиглості залежно від густоти стояння рослин; визначити урожайність зерна різних за стиглістю гібридів кукурудзи залежно від густоти стояння рослин.

Матеріали і методи досліджень

У дослідженнях вивчали вплив густоти посіву на ріст та продуктивність кукурудзи гібридів різної групи стиглості. Дослід проводили за такою схемою (рис. 1):

\section{1. Схема досліду}

\begin{tabular}{|l|l|l|l|l|l|}
\hline \multicolumn{1}{|c|}{ Групи скоростиглості та назва гібридів кукурудзи } & \multicolumn{5}{|c|}{ Густота стоянн рослин, тис./га } \\
\hline Ранньостиглий Р8521 (ФАО-220) & 65 & 70 & 75 & 80 & 85 \\
\hline Середньоранній PR39B76 (ФАО-280) & 60 & 65 & 70 & 75 & 80 \\
\hline Середньостиглий PR38N86 (ФАО-320) & 55 & 60 & 65 & 70 & 75 \\
\hline
\end{tabular}

Фенологічні спостереження проводили на досліджуваних рядках у двох несуміжних повторностях. Спостереження проводили візуально: відмічали початок фази, коли в неї вступило $10 \%$ рослин та повну - 75 \%. Відмічали дати сівби, появу сходів, цвітіння волотей, качанів, молочної, воскової і повної стиглостей качанів. Фази стиглості зерна визначали шляхом розрізання зернівки з середньої частини верхнього качана типових рослин. Повна стиглість настає при появі чорного прошарку на місті прикріплення зернівки. Облік густоти стояння рослин здійснювали підрахунком рослин на 14,3 погонних метрах $\left(10 \mathrm{~m}^{2}\right)$ з перерахунком їх у тисячі на гектар.

Висоту рослин, висоту прикріплення качанів, площу асиміляційної поверхні листя визначали після фази викидання волотей шляхом проміру 10 типових для цього варіанту рослин у двох несуміжних повтореннях. Висоту рослин вимірювали від поверхні грунту до верхівки волоті. Площу листкової поверхні розраховували, використовуючи параметри довжини та ширини листка за формулою Б. А. Доспєхова [8]:

$$
S=k \times l \times n,
$$

де $\mathrm{S}$ - площа листя, $\mathrm{cm}^{2} ; \mathrm{k}$ - середній поправочний коефіцієнт, що становить 0,$67 ; 1$ - довжина листя, см; $\mathrm{n}$ - ширина листка в самому широкому місці, см.

Вологість зерна кукурудзи, вихід зерна та урожайність визначали у пробах качанів (10 шт.), які відбирали на кожній обліковій ділянці. Урожай насіння перераховували на вологість 14 \%.

\section{Результати досліджень та їх обговорення}

Тривалість періоду вегетації гібридів кукурудзи на території України коливається від 90 до 150 днів. В. С. Циков [21] наводить такі параметри тривалості вегетаційного періоду і кількості листків на головному стеблі кукурудзи: ранньостиглі - 90-100 днів, числом листків - 14-15; середньоранні - 105-115 днів і 15-16 листків; середньостиглі - з вегетаційним періодом 115-120 днів і 17-18 листками; середньопізні - 120-130 днів і 18-19 листків; пізньостиглі - з вегетаційним періодом 135-140 днів і кількістю листків 19-20.

Залежно від агроекологічних умов та гібридів кукурудзи різних груп стиглості спостерігається неоднакова реакція щодо темпів росту і розвитку рослин під впливом густоти стояння. Окремі дані свідчать, що при збільшенні густоти стояння рослин період вегетації збільшується [19].

Низка вчених відмітили те, що при загущенні рослин тривалість міжфазних періодів змінювалась у межах 1-2 дні $[4,18,24]$.

У результаті досліджень, проведених у різних грунтово-кліматичних умовах, відносно впливу густоти стояння рослин на строки настання окремих фаз росту і розвитку та тривалість періоду вегетації одержані різні дані.

В умовах південно-східної частини Степу на Розівській дослідній станції у проведених дослідах при збільшенні густоти стояння рослин кукурудзи з 20 до 45 тис./га тривалість періоду сходи - викидання волоті збільшувалась на 1 день, а період викидання волоті - повна стиглість зменшувався на 1 день, зважаючи на що, загальний період вегетації практично не змінювався [17]. 


\section{СІЛЬСЬКЕ ГОСПОДАРСТВО. РОСЛИННИЦТВО}

На підставі проведених дослідів та спостережень в умовах північного Степу Луганської області та західного Лісостепу встановлено, що густота посіву кукурудзи не впливає на тривалість міжфазних періодів до утворення 8-го листка. У подальшому зі збільшенням густоти стеблостою фази розвитку проходять швидше [1, 23].

Наші дослідження підтверджують, що в середньому за роки досліджень мінімальний період вегетації спостерігався в ранньостиглого гібрида Р8521 - 122,8 діб, найтриваліший - у середньостиглого PR38N86 - 131,1-133,7 доби, середньораннього PR39B76 - 125,4-127,5 дні (табл. 2).

2. Тривалість міжфазних періодів вегетації гібридів кукурудзи різних груп стиглості залежно від густоти стояння рослин, діб (середне за 2018-2020 рр.)

\begin{tabular}{|c|c|c|c|c|c|}
\hline \multirow[b]{2}{*}{ Гібриди } & \multirow{2}{*}{$\begin{array}{c}\text { Густота } \\
\text { стояння рос- } \\
\text { лин, тис./га }\end{array}$} & \multicolumn{4}{|c|}{ Тривалість періодів } \\
\hline & & $\begin{array}{l}\text { сівба - } \\
\text { сходи }\end{array}$ & $\begin{array}{c}\text { сходи - цвітіння } \\
\text { волотей }\end{array}$ & $\begin{array}{c}\text { цвітіння волотей - } \\
\text { повна стиглість }\end{array}$ & $\begin{array}{c}\text { сходи - повна } \\
\text { стиглість }\end{array}$ \\
\hline \multirow{5}{*}{ P8521 } & 65 & \multirow{5}{*}{10,9} & \multirow{5}{*}{57,7} & \multirow{5}{*}{65,8} & \multirow{5}{*}{122,8} \\
\hline & 70 & & & & \\
\hline & 75 & & & & \\
\hline & 80 & & & & \\
\hline & 85 & & & & \\
\hline \multirow{5}{*}{ PR39B76 } & 60 & \multirow{5}{*}{10,8} & \multirow{3}{*}{60,5} & \multirow{4}{*}{65,2} & \multirow{3}{*}{125,4} \\
\hline & 65 & & & & \\
\hline & 70 & & & & \\
\hline & 75 & & 60,8 & & 126,1 \\
\hline & 80 & & 61,2 & 66,1 & 127,5 \\
\hline \multirow{5}{*}{ PR38N86 } & 55 & \multirow{5}{*}{10,9} & \multirow{4}{*}{62,6} & \multirow{3}{*}{69,2} & \multirow{3}{*}{131,4} \\
\hline & 60 & & & & \\
\hline & 65 & & & & \\
\hline & 70 & & & 69,6 & 133,1 \\
\hline & 75 & & 63,8 & 70,1 & 133,7 \\
\hline
\end{tabular}

Збільшення густоти рослин призводило до подовження періоду вегетації гібрида PR39B76 та гібрида PR38N86 - на 2,1 доби, гібрид P8521 виявився досить пластичним до зміни густоти стояння рослин, цей фактор не впливав на тривалість міжфазних періодів та вегетації загалом.

Розвиток рослин кукурудзи під впливом густоти стояння та погодних умов по роках у межах одного гібрида проходив з різною інтенсивністю. Варто відмітити, що із загущенням посіву тривалість періоду сходи - цвітіння волотей збільшувалась у гібрида PR39B76 залежно від густоти від 60 до 61 доби, у гібрида PR38N86 - від 62,6 до 63,8 доби, своєю чергою у гібрида P8521 тривалість такого періоду незалежно до зміни густоти стояння становила 57,7 діб.

У всіх гібридів тривалість періоду від цвітіння волотей до повної стиглості змінювалася несуттєво і була в межах 1-2 діб.

Отже, тривалість міжфазних періодів та періоду вегетації гібридів кукурудзи залежала від їх біологічних особливостей та погодних умов і майже не змінювалася під впливом густоти стояння рослин.

Реакція гібридів на загущення визначається біометричними показниками, серед яких висота рослин займає одне з головних місць. Існують різні твердження про вплив густоти стояння на темпи приросту рослин у висоту. Одержані дані свідчать, що при збільшенні густоти рослин кукурудзи висота їх збільшується. Результати спостережень у наших дослідах за динамікою росту кукурудзи свідчать, що у фазі 7-8 листків більшою висота рослин була у гібрида P8521 (64,8-65,9 см) (табл. 3).

У фазі 11-12 листків тенденція змінюється - максимальні темпи росту були у гібрида PR39B76 та гібрида PR38N86, мінімальні - P8521. Середньодобовий приріст склав відповідно - 5,8-6,2 см, 5,7-6,2 см та 5,4-5,7 см.

При проведенні обліків у фазі 13-14 листків максимальна висота рослин спостерігалась у середньораннього гібрида PR39B76 (179,8 см) при густоті 70 тис./га. У фазу цвітіння волотей висота рослин у ранньостиглого гібрида Р8521 була максимальною при густоті 75 тис./га і становила 192,4 см, у середньораннього PR39B76 при густоті 70 тис./га - 225,8 см та середньостиглого PR38N86 при густо- 
ті 65 тис./га - 227,3 см.

Відповідно до біологічних особливостей у рослин середньостиглого гібрида формувались рослини з більшою висотою, ніж у скоростиглих. При збільшенні густоти вищезазначених гібридів спостерігалося зменшення висоти рослин на 2,7 cм, 3,4 і 3,3 см відповідно. Отже, у фазу цвітіння волотей, коли рослини кукурудзи досягали своєї максимальної висоти, у вологий рік вона зростала від зріджених до загущених посівів, а в посушливі зменшувалась.

\section{3. Динаміка росту рослин гібридів кукурудзи різних груп стиглості залежно від густоти стояння} рослин, см (середнс за 2018-2020 рр.)

\begin{tabular}{|c|c|c|c|c|c|}
\hline \multirow{2}{*}{ Гібриди } & Густота стояння & \multicolumn{4}{|c|}{ Фази росту і розвитку рослин } \\
\cline { 2 - 6 } & рослин, тис./га & $7-8$ листків & $11-12$ листків & $13-14$ листків & цвітіння волотей \\
\hline \multirow{4}{*}{ P8521 } & 85 & 64,8 & 118,9 & 163,1 & 188,6 \\
\cline { 2 - 6 } & 80 & 65,6 & 121,3 & 165,2 & 189,6 \\
\cline { 2 - 6 } & 75 & 65,9 & 121,6 & 166,1 & 192,4 \\
\cline { 2 - 6 } & 70 & 65,9 & 122,7 & 164,8 & 190,3 \\
\hline \multirow{5}{*}{ PR39B76 } & 65 & 65,4 & 121,0 & 162,8 & 189,7 \\
\cline { 2 - 6 } & 80 & 63,6 & 124,3 & 173,6 & 222,9 \\
\cline { 2 - 6 } & 75 & 64,1 & 124,7 & 175,6 & 223,9 \\
\cline { 2 - 6 } & 70 & 64,3 & 126,1 & 179,8 & 225,8 \\
\cline { 2 - 6 } & 65 & 63,2 & 124,4 & 177,7 & 224,4 \\
\hline & 60 & 62,6 & 121,3 & 175,1 & 222,4 \\
\cline { 2 - 6 } & 75 & 62,7 & 122,7 & 175,1 & 224,2 \\
\cline { 2 - 6 } & 70 & 62,9 & 124,1 & 177,9 & 225,2 \\
\cline { 2 - 6 } & 65 & 64,2 & 126,3 & 179,3 & 224,9 \\
\cline { 2 - 6 } & 60 & 65,7 & 124,3 & 176,6 & 224,0 \\
\hline
\end{tabular}

Відповідно до біологічних властивостей середньопізнього гібрида PR38N86 його рослини перевищували за висотою ранньостиглий P8521 і середньоранній PR39B76. Отже, характеристика динаміки висоти рослин дає змогу зробити висновок, що цей показник залежить не тільки від густоти посіву, біологічних особливостей гібрида, але і від погодних умов у період вегетації кукурудзи.

Урожай кожної культури, зокрема і кукурудзи, визначається середньою продуктивністю однієї рослини та кількістю рослин на одиниці площі. Під впливом густоти стояння рослин суттєво змінюються такі елементи продуктивності, як довжина качанів, маса 1000 зерен, озерненість качана, а також кількість качанів на 100 рослин. Причому при відхиленні густоти від оптимальної у сторону зріджених посівів рівень указаних показників збільшується, а при загущенні - зменшується. Різна скоростиглість гібридів і визначення оптимальної густоти, з огляду на морфо-біологічні особливості, є резервом збільшення урожаю.

За даними В. Н. Багринцевої [3, 4], по мірі загущення рослин продуктивність зменшується, але порізному для кожної групи стиглості. Менше знижується продуктивність рослин зі збільшенням густоти стояння рослин у ранньостиглих, середньоранні і середньостиглі гібриди сильніше реагують на зміну густоти. Іншими словами, чим пізньостигліший гібрид, тим значно зменшується індивідуальна продуктивність по мірі збільшення густоти.

Як свідчать дані наших досліджень, у середньому за роки їх проведення показники індивідуальної продуктивності істотно варіювали під впливом густоти стояння рослин, морфо-біологічних особливостей гібридів і погодних умов (табл. 4).

Максимальну кількість продуктивних качанів на рослинах формував ранньостиглий гібрид Р8521 - 116,7 шт., мінімальну - середньоранній PR39B76 - 108,3 шт. та середньостиглий PR38N86 111,7 шт. при найменшому рівні густоти. 3 поступовим загущенням показники індивідуальної продуктивності зменшувались. При збільшенні густоти рослин з 65 до 85 тис./га у гібрида Р8521 кількість качанів на 100 рослинах зменшувалась на 16 штук, у гібрида PR39B76 - на 17 штук та гібрида PR38N86 - на 18 штук. 
4. Індивідуальна продуктивність рослин гібридів кукурудзи різних груп стиглості залежно від густоти стояння рослин (середнє за 2018-2020 рр.)

\begin{tabular}{|c|c|c|c|c|c|}
\hline & & \multirow{2}{*}{\multicolumn{3}{|c|}{ Кількість рослин, \% }} & \multirow{3}{*}{$\begin{array}{l}\text { Кількість продуктивних ка- } \\
\text { чанів на } 100 \text { рослинах, штук }\end{array}$} \\
\hline \multirow[b]{2}{*}{ Гібриди } & \multirow{2}{*}{$\begin{array}{l}\text { Густота стояння } \\
\text { рослин, тис./га }\end{array}$} & & & & \\
\hline & & $\begin{array}{c}3 \text { одним } \\
\text { качаном }\end{array}$ & $\begin{array}{c}3 \text { двома ка- } \\
\text { чанами }\end{array}$ & $\begin{array}{c}\text { без ка- } \\
\text { чанів }\end{array}$ & \\
\hline \multirow{5}{*}{ P8521 } & 65 & 83,3 & 16,7 & - & 116,7 \\
\hline & 70 & 87,3 & 12,7 & - & 112,7 \\
\hline & 75 & 90,7 & 9,3 & - & 109,3 \\
\hline & 80 & 92,7 & 6,7 & 0,6 & 106,0 \\
\hline & 85 & 96,7 & 2,0 & 1,3 & 100,7 \\
\hline \multirow{5}{*}{ PR39B76 } & 60 & 91,7 & 8,3 & - & 108,3 \\
\hline & 65 & 95,7 & 4,3 & - & 104,3 \\
\hline & 70 & 99,3 & 0,7 & - & 100,7 \\
\hline & 75 & 95,3 & - & 4,7 & 95,3 \\
\hline & 80 & 91,3 & - & 8,7 & 91,3 \\
\hline \multirow{5}{*}{ PR38N86 } & 55 & 88,3 & 11,7 & - & 111,7 \\
\hline & 60 & 92,0 & 8,0 & - & 108,0 \\
\hline & 65 & 95,3 & 4,7 & - & 104,7 \\
\hline & 70 & 97,0 & - & 3,0 & 97,0 \\
\hline & 75 & 93,7 & - & 6,3 & 93,7 \\
\hline
\end{tabular}

Потрібно відзначити, що досить толерантним до рівня загущення виявився ранньостиглий гібрид P8521, навіть при збільшенні густоти до 80-85 тис./га кількість рослин без качанів була в межах 0,6-1,3 \% на 100 рослин, а у гібрида PR39B76 до 75-80 тис./га - 4,7-8,7 і PR38N86 до 70-75 тис./га - 3,0-6,3 \%.

Дослідження свідчать, що показники індивідуальної продуктивності зменшуються по мірі загущення. На нашу думку, основним резервом збільшення виробництва товарного зерна є визначення оптимальної густоти для гібридів кукурудзи різних груп стиглості, зважаючи на агроекологічні умови.

Оптимальну кількість качанів, при якій найкраще поєднуються показники індивідуальної продуктивності і кількості рослин на одиниці площі, у ранньостиглого гібрида P8521 досягали у варіантах 3 густотою стояння 75 тис./га, у середньораннього PR39B76 - 70 тис./га і середньостиглого PR38N86 70 тис./га.

Наукові роботи багатьох дослідників доводять, що густота стояння рослин кукурудзи має істотний вплив на формування структурних елементів урожаю. Результати досліджень показали суттєвий вплив густоти стояння на такі елементи продуктивності, як довжина качана, маса зерна 3 качана, озерненість залежно як від густоти, так і від агроекологічних умов року. При загущенні посіву до максимального рівня маса зерна з качана у ранньостиглого гібрида зменшилась на 18,6 г, у середньораннього - на 28,2 г та середньостиглого - на 34,2 г.

Відмічено зростання діапазону мінливості лінійних розмірів качана та маси зерна при переході від ранньостиглої форми до більш пізніх. Озерненість качана була найвищою при густоті 75 тис./га у гібрида P8521, 70 тис./га у гібрида PR39B76 та 65 тис./га у гібрида PR38N86 - відповідно 82,2 \%, 83,5 \% і 79,8 \%, а мінімальною - при максимальній густоті стояння рослин по гібридах 85, 80 і 75 тис./га відповідно 80,4 \%, 80,9 \% і 78,1 \%.

Отже, густота стояння рослин істотно впливала на формування елементів структури урожаю зерна, що врешті-решт позначилося на урожайності. Маса зерна з качана та довжина качана при загущенні рослин зменшувались.

Урожайність зерна визначається співвідношенням кількості рослин на одиниці площі і їх індивідуальною продуктивністю. Тому підбір оптимальної густоти стояння рослин дає змогу отримувати високі і стабільні урожаї зерна та знизити витрати на післязбиральне його досушування.

Дані обліку урожаю зерна в наших дослідах показали, що величина цього показника за роки досліджень залежала від густоти стояння рослин, морфо-біологічних особливостей гібридів та агроекологічних умов року.

Істотний вплив на формування урожайності гібридів мала густота стояння рослин. Максимальна 
урожайність була у гібрида Р8521 у разі густоти стояння 75 тис./га $(75,1$ ц/га). При зменшенні густоти стояння на 5 тис. урожайність зменшилась на $3,3 \%$, а за густоти стояння 65 тис./га була на рівні 70,4 ц/га, що менше, ніж при 60 тис./га на 6,3\%. Урожайність за густоти стояння 80 тис./га була 72,2 ц/га, що менше на 3,9 \% і за густоти стояння 85 тис./га - 69,7 ц/га, що менше на 7,2 \% (рис.).

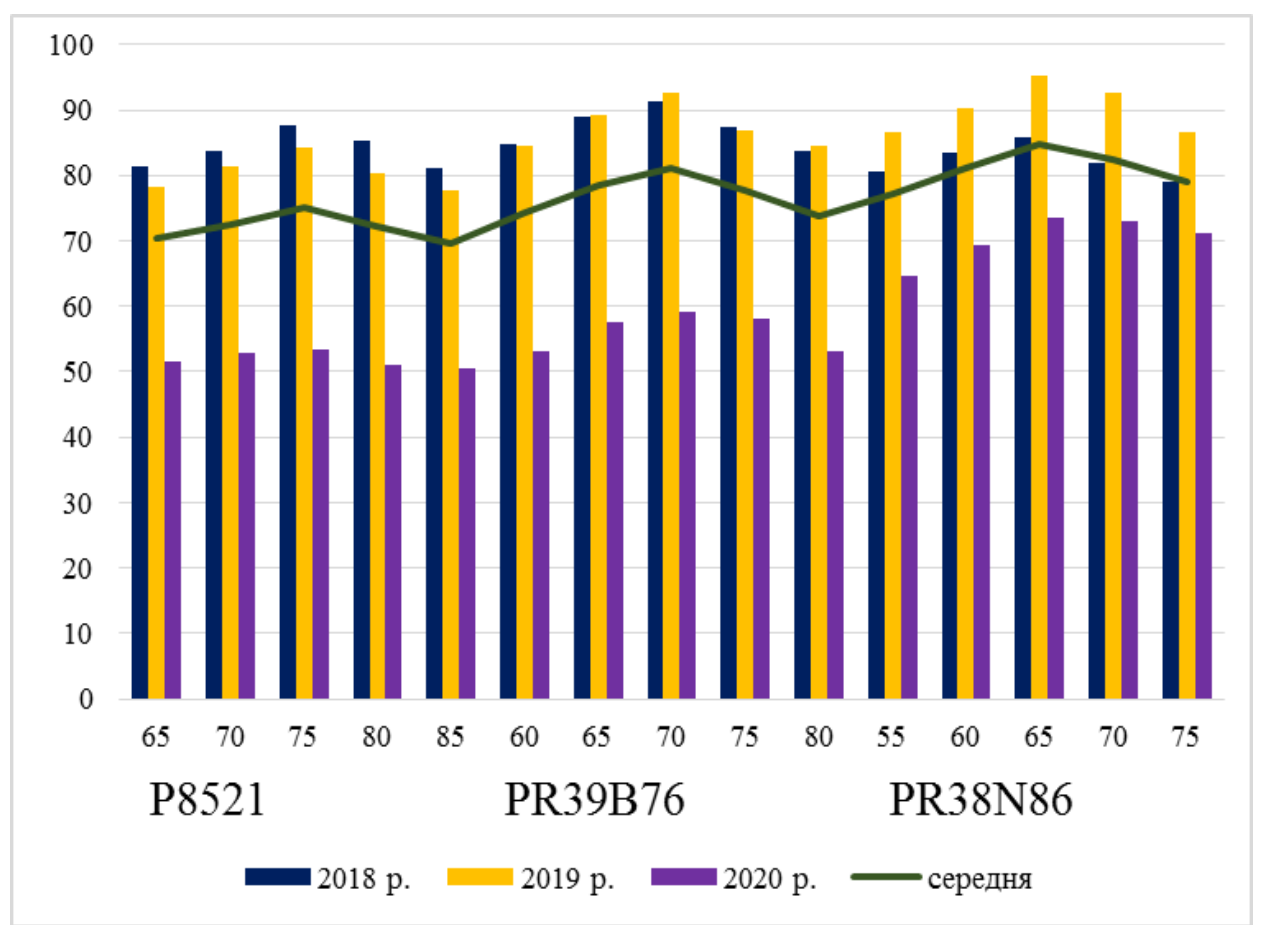

Рис. Урожайність зерна різних за стиглістю гібридів кукурудзи залежно від густоти стояння рослин,

Примітки: по вертикалі - густота стояння рослин, тис./га; по горизонталі - урожайність гібридів кукурудзи по рокам та середня, ц/га.

Стосовно гібрида PR39B76 максимальна урожайність становила 81,0 ц/га за густоти стояння рослин 70 тис./га, при зменшенні густоти до 60-55 тис./га урожайність зменшилась на 3,1-8,4 \%, збільшення щільності стеблостою до 75-80 тис./га призводило до зниження врожайності на 4,2-8,9\%.

Дослідження підтверджують, що максимальну урожайність зерна в середньому за роки проведення досліджень сформував середньостиглий гібрид PR38N86. Найменший рівень продуктивності в середньому за роки досліджень серед гібридів показав ранньостиглий Р8521. Так, залежно від густоти стояння рослин урожайність зменшувалася передовсім при загущенні рослин гібрида Р8521 до 85 тис./га, PR39B76 - до 80 тис./га. PR38N86 високий рівень урожайності забезпечив при густоті 65 тис./га $-84,8$ ц/га.

Доцільно додати, що НІР 0,95 для густоти стояння рослин та гібридів за роками становив, відповідно: 2018 р. - 1,3 і 1,0; 2019 р. - 1,1 і 0,8; 2020 p. - 2,4 і 1,8.

Значний вплив на формування урожайності гібридів здійснювали агроекологічні умови року. У посушливих умовах 2020 р., внаслідок занадто високих значень температури повітря і недостатньої кількості опадів у літній період рівень урожайності був мінімальним порівняно з 2018-2020 pp. В умовах 2020 р. урожайність зерна у ранньостиглого гібрида Р8521 залежала від густоти стояння на рівні 51,5-50,4 ц/га, у середньораннього PR39B76 - 53,1 ц/га і середньостиглого PR38N86 $64,7-71,2$ ц/га.

У прохолодному та вологому 2018 р. висока зернова продуктивність була у ранньостиглого гібрида P8521 - 81,4-81,0 ц/га і середньораннього PR39B76 - 84,9-83,8 ц/га і дещо меншою у середньостиглого PR38N86 - 80,6-78,9 ц/га. У всі роки взаємодія факторів біотипу гібридів і густоти стояння рослин суттєво впливала на формування урожаю, що свідчить про необхідність визначення оптимальних параметрів густоти при вирощуванні кожного гібрида в конкретних кліматичних умовах. 


\section{Висновки}

Отже, на основі результатів, отриманих під час проведення виробничих досліджень гібридів кукурудзи, ми можемо зробити такі попередні висновки:

1. За даними урожайності одним із оптимальних технологічних заходів вирощування ранньостиглого гібрида P8521 є густота стояння рослин 75 тис./га, середньораннього PR39B76 - 70 тис./га та середньостиглого PR38N86 - 65 тис./га.

2. Порівнюючи між собою варіанти за даними економічної ефективності, можна стверджувати, що одним із оптимальних технологічних заходів вирощування ранньостиглого гібрида Р8521 є густота стояння рослин 75 тис./га, середньораннього PR39B76 - 70 тис./га та середньостиглого PR38N86 65 тис./га.

B перспективі плануємо дослідити норми висіву кукурудзи та підвищення стійкості досліджуваних гібридів до хвороб та шкідників.

\section{References}

1. Andriienko, A. M. (2003). Fotosyntetychna diialnist ta produktyvnist novykh hibrydiv kukurudzy zalezhno vid hustoty stoiannia roslyn. Biuleten Instytutu Zernovoho Hospodarstva, 20, 36-38 [In Ukrainian].

2. Arkhypenko, O. M., Artiushchenko, A. O., \& Kukharchuk, O. I. (2005). Ahrotekhnichni zakhody pidvyshchennia produktyvnosti ta pozhyvnosti kukurudzy. Visnyk Ahrarnoi Nauky, 6, 15-18 [In Ukrainian].

3. Bagrinceva, V. N. (2001). Urozhajnost kukuruzy pri raznoj gustote stoyaniya. Kukuruza i Sorgo, 6, 2-3 [In Russian].

4. Bagrintseva, V. N., Borsch, T. I., \& Sharapova, I. A. (2001). Urozhaynost gibridov kukuruzyi pri raznoy gustote stoyaniya rasteniy. Kukuruza i Sorgo, 5, 2-4 [In Russian].

5. Barabolia, O. V., \& Hryshko, M. (2015). Vplyv strokiv sivby kukurudzy na urozhainist ta yakist zerna. Innovatsiini aspekty tekhnolohii vyroshchuvannia, zberihannia i pererobky produktsii roslynnytstva : materialy III naukovo-praktychnoi konferentsii (21-22 kvitnia 2015 roku). Poltava: PDAA [In Ukrainian].

6. Barabolia, O. V., Kalinichenko, V. I., \& Petrachenkov, V. V. (2018). Tekhnolohiia vyroshchuvannia kukurudzy na zerno. Materialy II Vseukrainskoi naukovo-praktychnoi konferentsii (29 kvitnia 2018 roku). Poltava, PDAA [In Ukrainian].

7. Barabolia, O. V., Liashenko, V. V., \& Podoliak, V. A. (2020). Stroky sivby yak osnovnyi chynnyk formuvannia ahroekolohichnykh umov vyroshchuvannia kukurudzy : kolektyvna monohrafiia. Ekolohichni innovatsii u pidvyshchenni ekonomichnoi ta prodovolchoi bezpeky Ukrainy. Poltava, PDAU [In Ukrainian].

8. Dospehov, B. A. (1989). Metodika polevogo opyta s osnovami statisticheskoj obrabotki rezultatov issledovanij ; 5-e izdanie pererabotannoe i dopolnennoe. Moskva: Agropromizdat [In Russian].

9. Dychenko, O. Yu., \& Chaika, T. O. (2017). Osnovni tekhnolohichni aspekty vyroshchuvannia kukurudzy. O. I. Ulianych (vidp. red.). Ovochivnytstvo Ukrainy: istoriia, tradytsii, perspektyvy : materialy Mizhnarod. nauk.-prakt. konf., prysviachenoi 95-richnytsi stvorennia kafedry ovochivnytstva. Uman: Vizavi [In Ukrainian].

10. Hryhorieva, O. M., \& Hryhorieva, T. M. (2006). Urozhainist zerna hibrydiv kukurudzy zalezhno vid hustoty roslyn i tekhnolohichnykh modelei v umovakh pivnichnoho Stepu Ukrainy. Zbirnyk naukovoho prats Umanskoho DAU, 63, 31-35 [In Ukrainian].

11. Mynkin, M. V., Berdnikova, O. H., \& Mynkina, H. O. (2019). Formuvannia produktyvnosti kukurudzy na zerno zalezhno vid zhyvlennia ta hustoty stoiannia v umovakh Pivdnia Ukrainy. Tavriiskyi Naukovyi Visnyk, 106, 103-109 [In Ukrainian].

12. Nechaev, V. F. (2001). Osobennosti vozdelyvaniya kukuruzy. Kukuruza i Sorgo, 3, $2-5$ [In Russian].

13. Orlyanskij, N. A., \& Orlyanskaya, N. A. (2005). Povedenie kukuruzy v usloviyah isskustvennogo stressa, vyzvannogo zagusheniem posevov. Kukuruza i Sorgo, 4, 5-8 [In Russian].

14. Orlyanskij, N. A., Orlyanskaya, N. A., \& Zubko, D. G. (2005). Selekciya kukuruzy na adaptivnost i zagushenie posevov. Kukuruza i Sorgo, 5, 2-4 [In Russian].

15. Pospielova, H. D., Chaika, T. O., \& Okhrimenko V. V. (2020). Vplyv fitopatohennoho stanu posiviv kukurudzy na yii produktyvnist. T. O. Chaiky, I. O. Yasnolob, O. O. Horba (Reds.). Ekolohichni innovatsii u pidvyshchenni ekonomichnoi ta prodovolchoi bezpeky Ukrainy : kolektyvna monohrafiia. (s. 217-227). Poltava: Astraia [In Ukrainian].

16. Pospielova, H. D., Chaika, T. O., \& Okhrimenko, V. V. (2020). Mistse fitosanitarnoho monitorynhu v intehrovanykh systemakh zakhystu roslyn kukurudzy vid khvorob. Perspektyvy eko-innovatsiinoho rozvytku 


\section{СІЛЬСЬКЕ ГОСПОДАРСТВО. РОСЛИННИЦТВО}

silskohospodarskoho vyrobnytstva : materialy II Mizhnar. nauk.-prakt. konf. Poltava: RVV PDAU [In Ukrainian].

17. Pysarenko, P. V., Lavrynenko, Yu. O., \& Kokovikhin, S. V. (2002). Hustota stoiannia roslyn hibrydiv kukurudzy v umovakh pivdennoho Stepu. Khranenye y Pererabotka Zerna, 7, 28-30 [In Ukrainian].

18. Slyudeev, Yu. A. (2003). Produktivnost gibridov kukuruzy pri razlichnoj gustote stoyaniya rastenij i dozah udobrenij na vyshelochnyh chernozemah Ryazanskoj oblasti. Kukuruza i Sorgo, 4, 6-8 [In Russian].

19. Tanchyk, S. P., Mokriienko, V. A., Anidzelskyi, V., \& Zhuravlova, N. V. (2004). Formuvannia produktyvnosti kukurudzy zalezhno vid hustoty posivu. Zbirnyk Naukovykh Prats Instytutu Zemlerobstva UAAN, 1, 80-83 [In Ukrainian].

20. Taranenko, S. V., Chaika, T. O., \& Tiupka, Ya. V. (2019). Ahroekonomichna efektyvnist riznykh sposobiv osnovnoho obrobitku gruntu na posivakh kukurudzy. Visnyk Poltavskoi Derzhavnoi Ahrarnoi Akademii, 4, 66-72. doi: 10.31210/visnyk2019.04.08 [In Ukrainian].

21. Tsykov, V. P. (2000). Osoblyvosti tekhnolohii vyroshchuvannia kukurudzy v umovakh nedostatnoho i nestiikoho zvolozhennia stepovoi zony Ukrainy. Propozytsiia, 4, 39-41 [In Ukrainian].

22. Vasilenko, V. V. (2006). Tochnost razmesheniya rastenij i urozhaj. Kukuruza i Sorgo, 5, 9-10 [In Russian].

23. Yakunin, O. P., \& Zavertaliuk, V. F. (2002). Pidvyshchennia vrozhainosti kukurudzy v umovakh pivnichnoho Stepu. Khranenye y Pererabotka Zerna, 6, 26-28 [In Ukrainian].

24. Zaporozhets, Zh. M., \& Savchenko, S. P. (2004). Vplyv hustoty roslyn na vrozhainist imbrednykh linii ta hibrydiv kukurudzy. Umanskomu DAU - 160 rokiv : materialy Vseukrainskoi konferentsii molodykh vchenykh. Uman, 2004 [In Ukrainian].

Стаття надійшла до редакції 17.02.2021 р.

Бібліографічний опис для цитування:

Жемела Г. П., Бараболя О. В., Ляшенко В. В., Ляменко С. С., Подоляк В. А. Формування продуктивності зерна гібридами кукурудзи залежно від норми висіву. Вісник ПДАА. 2021. № 1. С. 97-105.

(C) Жемела Григорій Пимонович, Бараболя Ольга Валерї̈на, Ляменко Віктор Васильович, Ляменко Свген Сергійович, Подоляк Віталій Анатолійович, 2021 